\title{
Professor Watson's Memoirs
}

The publication in the United States of Professor J. D. Watson's book The Double Helix has established a claim on polite conversation which is not entirely stifled even by public concern about the relationship between gold and the dollar or even by the drama of the first manoeuvres in the election of a new president. That, to say the least of it, is a proof of the importance of a book intended to provide a full account of the way in which, in the early fifties, Watson and Crick felt or fumbled their way towards a correct structure for the DNA molecule. Professor Watson's book is not, however, a formal history but rather a personal recol. lection of events - a memoir. Many will dissent from his assertion, in a preface, that "no-one will ever be able to write a definitive history of how the structure was established", but in any case this is not Professor Watson's chief concern. He is quite honestly, and quite properly, concerned to convey the flavour of how scientific research is "done", to use his own words. In doing so he has necessarily flown in the face of several conventions, literary and social. This in turn has no doubt lost him his place on a good many Christmas card lists, but that is his concern.

In the circumstances, an objective appraisal of the value of the book as literature or as history is probably too much to hope for. Most critics so far have been deprecatory and somewhat patronizing, but they have usually also been in positions to feel threatened, directly or otherwise, by what Professor Watson has to say. It will be easier to tell when The Double Helix is eventually published in Britain two months from now, after what must seem an absurd delay. In the meantime, however, there is no doubt that Professor Watson has written a rattling good yarn, quite spellbinding. It bounces along like a detective story and will probably be a great success. This is a tribute to Professor Watson's engaging candour. He might have been better than Boswell and certainly funnier.

There remains the question of how the issues of principle raised by the book are to be dealt with. The first thing to acknowledge, however, is that there should be no difficulty at all in what seems most commonly to have been the offence the way in which this personal account of events is necessarily subjective and even distorting. If, for example, one of the participants is repeatedly presented as over-ebullient or overcautious, this is to be read more as a comment on the relationship between Professor Watson and the people concerned than as a truth that the qualities described are real. If some people seem larger than life, or smaller than life, it may well be that the fault lies in Professor
Watson and not his cast of characters. To be sure, publication of the book will be a chastening experience for many molecular biologists, and some of them, no doubt, will be offended, but that is one of the hazards of this kind of literature.

The way in which the book is larded out with tales of Professor Watson's pursuit of young women at Cambridge may also seem to other participants to be undignified. Others, however, may reoognize that unmarried graduate students often share the same weaknesses. In reality, these and other incidents in the book are one of the sources of its credibility and a valuable clue to Professor Watson's estimation of his own part in the problem of DNA. If, of course, his picture is seriously awry, then other people are free to protest and even have a duty to do so. It is not enough simply to resolve never again to invite Professor Watson to tea and biscuits.

It is in passing worth remarking that the techniques which have been used in constructing this book are commonly and rightly eschewed by professional reporters as a means of getting at the truth. What Professor Watson has done is to write down the often unguarded statements of those concerned with the working out of DNA. The trouble, of course, is that statements like these may be misleading. If $X$ complains angrily of $Y$, for example, it does not follow that the complaint is justified, or even that $\mathrm{X}$ is habitually hostile to $Y$. To know the truth, both $X$ and $Y$ must be cross-examined by some third party and even then the truth may be elusive.

These, however, are almost technical objections and certainly do not suggest that The Double Helix should never have been published. The way in which this enthralling book provides non-professional readers with an occasional unseemly view of science and of research is another issue likely to lose Professor Watson friends. But is he wrong? A good deal of what he has to say, for example, about the sense of competition between the group at Cambridge and its rivals-real and imaginary-elsewhere may come as something of a shock to those outside. But is competitiveness all that uncommon ? And is it sensible of professional scientists sometimes to pretend that feelings like this never sully the state of science? In fact what Professor Watson has done is to provide a much more real appraisal of the character of science in the laboratory than other published statements of a more formal kind. He has done something to ensure that science will become less pompous than it is. For all the faults which may be found in The Double Helix. this is a considerable public service. 